\title{
CLIENT NETWORKS
}

\author{
Angelika Lindstrand* \\ Stockholm School of Economics \\ Department of Marketing \\ Box 6501 \\ 11383 Stockholm \\ Sweden \\ Phone +46 87369000 \\ E-mail angelika.lindstrand@hhs.se
}

\author{
Kent Eriksson \\ KTH - The Royal Institute of Technology \\ Box 10044 Stockholm \\ Sweden \\ Phone +46 702092612 \\ E-mail kent.eriksson@infra.kth.se
}

and

D. Deo Sharma

Stockholm School of Economics

Department of Marketing

Box 6501

11383 Stockholm

Sweden

Phone +46 87369545

E-mail dds@hhs.se

*Corresponding author. 


\title{
THE PERCEIVED USEFULNESS OF KNOWLEDGE SUPPLIED BY FOREIGN CLIENT NETWORKS
}

\begin{abstract}
The network surrounding a firm's foreign clients has large influence on its ability to act in the market. How firms can utilize the knowledge supplied by client networks is therefore of great importance to their business with clients. Many studies show the usefulness of foreign clients and suppliers, whereas less attention has been given to the usefulness of knowledge supplied by clients' network, such as clients' clients, clients' supplementary suppliers and competitors to the firm. This study contributes to international business research on networks by investigating the knowledge supplied by client networks for a firm doing business with a specific foreign client on a sample of 494 firms. A LISREL analysis demonstrates that knowledge supplied by client networks is more useful the more experienced the firm. Client networks are also more useful the more knowledge the firm has of its client, the more the firm needs knowledge of its clients and suppliers, the higher the cost of the client relationship, and the more standardized the product. A major conclusion is that the client network knowledge is more useful the further a firm's collaboration with the client, presumably as a result of the new, and more embedded business that the firm develops with the client. Implications are that client networks are resources that can be important competitive advantages for the internationalizing firm.
\end{abstract}




\section{Introduction}

Studies have found that international business relationships are surrounded by business networks (Blomstermo, Eriksson, Lindstrand and Sharma 2004, Welch and Wilkinsson 2005), political networks (Welch and Wilkinsson 2004), and supply networks (Walter, Müller, Helfert and Ritter 2003). In a foreign expansion, the internationalizing firm often seeks to develop business with a client, either via direct export, or via some other establishment form. Several studies identify the strategic importance of understanding a foreign client's network (Bridgewater 1999, Gilmore, Carson and Rocks 2006), but, to our knowledge, no studies have so far studied the usefulness of client networks for development of business with the clients. Client network ties are those that have a direct business exchange with the client, but not with the firm (see Figure 1). Examples of client network ties are clients' clients, competitors, clients’ complementary suppliers. As can be inferred from studies of network ties by Johanson and Mattsson (1987), client networks are an important source of knowledge and information to firms. Client networks may supply knowledge about competitors, supply chain linkages, or market research of demand for clients’ products (Lindstrand, 2003).

\section{Put Figure 1 here}

In international business related decision making not all knowledge is perceived to be equally useful (Cavusgil 1985), some types of knowledge are more useful than other types. The reason for some knowledge being more useful than others has many explanations, such as firm internal processes (Shahana and Tuzhilin 1998), uncertainty (Wilkinson and Young 2005), or the market focus (Blankenburg Holm and Eriksson 2000). When doing business 
with a client, a firm may find knowledge about client networks useful. Thus, to advance network studies in international business, there is a need for researching the perceived usefulness of knowledge supplied by client network ties in international business.

Based on the internationalization process model (Johanson and Vahlne 1977), the experience effect establishes a connection between firm experiences and firm internal processes (Delios and Beamish 2001). However, the nature of this connection is still a 'black box', even though several studies reveal a relationship between experience and outcome, such as performance (e.g. Barkema, Bell \& Pennings, 1996; Erramilli, 1991; Hitt, Hoskisson \& Kim, 1997; Levinthal \& March, 1993; Luo \& Peng, 1999). The perceived usefulness of knowledge has been found a kind of perception that is a strong predictor of behavior (Davis, Bagozzi and Warshaw 1989, Venkatesh and Davis 2000). Perceived usefulness can be considered a mediating variable between perception and behavior, which is central to the understanding of how experiences make firms develop and use knowledge in firms internal processes (Eriksson, Johanson, Majkgard and Sharma 1997). For this reason, the research presented in this paper used an empirical research design that frames the perceived usefulness of a client's network ties within an ongoing international business relationship with a client. An ongoing international business relationship is a current decision making situation that is of great importance to the internationalizing firm, and may concern an international expansion via export, or other modes of establishment.

The purpose of this paper is thus to study the 'perceived usefulness' of client networks for international expansion with a client.

A delimitation of this study is that performance is not studied. Previous research has found a link between international business network development in general and performance (Blankenburg Holm, Eriksson and Johanson 1999). Future research can study the link 
between performance and the perceived usefulness of knowledge supplied by a client's network.

The paper begins with a discussion of the knowledge in firms. Thereupon, the issue of perceived usefulness of knowledge and the network connections in firms are presented. Based on the above, five hypotheses are developed and tested with the help of LISREL. The data and results are then presented, and we conclude with a discussion of some future research issues.

\section{The Perceived Usefulness of knowledge from client networks, client tie, and firms' international experience}

By knowledge accumulation or learning is implied 'the process within the organization by which knowledge about action-outcome relationships and the effect of the environment on these relationships is developed' (Duncan and Weiss 1979, p. 84). Knowledge contains assumptions, causal maps, strategic orientations (March and Olsen 1976; Hall 1984), and operating procedures (March and Simon 1958). Knowledge in firms is based on history and trial and error (Levitt and March, 1988), deposited in its routines (Nelson and Winter 1982), and forms a firm’s theory-in-use (Argyris and Schön 1978, Fiol and Lyles 1985, Corsini 1987). The firm's theory-in-use can furthermore be seen as its interpretative schemes (Ranson, Hinings and Greenwood 1980), or organizational frames of reference (Shrivastava and Schneider 1984). Theory-in-use helps the firms understand the cause and effect relationship and guides the behavior of decision-makers including what information they perceive as useful and how it is interpreted.

Firms accumulate knowledge from their experience at the level of the individual international business relationship, at the level of the local market, and at the international level (Eriksson et 
al. 1997). Knowledge accumulation is, generally, incremental, and occurs as firms make resource commitments in ongoing international business relationships. Knowledge accumulation in firms is dynamic and involves a number of different steps, e. g., information generation, dissemination, interpretation or sense making, and information storing for future use (Huber 1991; Sinkula 1994). The firm develops an 'absorptive capacity', meaning an ability to assimilate knowledge from experiences and apply it to commercial ends (Cohen and Levinthal 1990). Differences in the theory-in-use in firms have a considerable influence on differences in preferences and performance (Huber 1991). What knowledge is perceived as useful is, consequently, contingent on the firm's theory-in-use. This determines a firm's perception of, and methods for, handling their environment (Daft and Weick 1984; Slater and Narver 1995). By usefulness of knowledge is implied 'the perceived potential the information has for usage' (Menon and Varadarajan 1992, p. 66). The usefulness of knowledge is the ability of the knowledge to provide decision-makers with a rationale upon which to make their decisions, and thereby to promote action. These perceptions may not necessarily be correct in light of the environment or their organization's resources, but reflect the firm's enacted view of a rationality that they use in the firm (Weick 1969).

The usefulness of knowledge is recognized through interaction with other actors, because interaction generates experiences that increase the knowledge of how to use information i.e. future usefulness (Venkatesh and Davis 2000). The usefulness of knowledge is developed in a process since ongoing business relationships provide experiences that result in new knowledge in the future (Johanson and Vahlne 1977). Experiences are made at the level of the ongoing business itself, at the level of the local market, and at the international level from a number of country markets (Chetty, Eriksson, and Lindberg 2006).

At any given point in time, firms are embedded in network of inter-connected exchange relationships, some directly with a client, and others indirectly through the client. The client 
ties and the client network ties differ in the useful knowledge they supply for the firm (Blomstermo, Eriksson, Johanson and Sharma 2000). Client ties supply more standard and routine knowledge in much the same way that strong ties (Granovetter 1973) and coproduction in supply chain linkages does (Walter et al. 2003). The knowledge supplied by client network ties can be conceptualized as a subset of weak ties, and a subset that concerns only those weak ties that relate directly to the customer. The client network ties often display the same features as weak ties, meaning a more numerous and more heterogeneous set of ties, where there is a lower degree of connection and frequency of interaction (Granovetter 1973). Client network ties can supply more novel knowledge because they span structural holes (Burt 1982).

Based on the above, we may expect that the perceived usefulness of client network ties should depend on knowledge of a) an ongoing business relationship, b) a local market, and c) varied country markets. For instance, concerning knowledge of an ongoing business relationship, involvement in the relationship affects the use of marketing information (Zinkhan, Joachimsthaler, and Kinnear 1987). Other findings by Deshpande and Zaltman (1982), included the fact that the higher the degree of surprise in the information, the less its use, meaning that more standardized and accessible market information is more useful. When it comes to local market knowledge, the firm's own other clients and suppliers may provide a context that defines the perceived usefulness of the client networks in a local market. Assessment of both costs of and knowledge needed to work with other clients and suppliers in development of an ongoing business will determine the perceive usefulness of client networks (Anderson, Håkansson, and Johanson 1994; Hallén, Johanson, and Seyed-Nazeem 1991, Eriksson et al. 1997). Varied country market knowledge often facilitate a higher order learning that makes a firm better able to adjust their theory-in-use to local markets (Eriksson 
et al. 2000), and consequently, also be better able to perceive the usefulness of knowledge from client networks.

\section{Client networks and Usefulness of Knowledge: Hypotheses}

\section{Knowledge of an ongoing business relationship and usefulness of knowledge supplied by client networks}

Firms develop knowledge from experiences of dealing with their clients. Client specific experiences have been found to result in commitments that develop the relationship further (Anderson and Weitz 1992). A firm's involvement with a counterpart is an incremental, gradual and time consuming process (Ford 1980; Jackson 1985; Dwyer, Schurr and Oh 1987). In the course of the evolution of a relationship, firms accumulate knowledge of their counterpart, make adaptations and commit resources (Morgan and Hunt 1994; Gundlach, Achrol, and Mentzer 1995; Heide and John 1992; Hallén et al. 1991). Such relationship specific knowledge has also been found an important competitive advantage as investment in developing relationship specific assets are the most potent drivers of relationship development and profitability increase (Anderson and Weitz 1992; Blankeburg Holm et al. 1999). The accumulation of knowledge supplied by a specific client is time and resource consuming, and the longer and more a firm is involved in a client relationship, the more of its unique network context will it discover (Levinthal and Fichman 1988, Goodman, Fichman, Lerch and Snyder 1995). More involvement in a specific client thus leads to more perceived usefulness of knowledge from client networks. Thus,

H1: The greater a firm's involvement with a client, the greater the 
perceived usefulness of knowledge from client networks will be.

We stated earlier that knowledge supplied by ties to clients is more useful in repetitive and programmed decision situations. The higher the degree of programming and standardization in the decision situation, the easier it is to extrapolate past into future, and when faced with a problem or opportunity, firms seek knowledge in the vicinity of their successful past actions. In such decision situations, the standardized operating procedures and routines are perceived as valid and applicable in the future (Simon 1961). The more standardized the product offered by firms is, the more routine and programmed marketing decision making is. In such decision situations, the less the need for the kind of new and innovative knowledge supplied by firms' client networks. On the other hand, the more non-standardized the products and services are, the greater the need for new and innovative knowledge, questioning, trial and error, and experimentation will be (March 1991). In such unstandardized decision situations, the more useful the client network will be perceived to be. Based on the above, we expect an unstandardized product to require innovative and new knowledge, and hence we expect the usefulness of the knowledge supplied by client network ties to be greater. Therefore,

H2: The less standardized the product supplied by a firm, the greater the perceived usefulness of knowledge supplied by client networks will be.

\section{Local market knowledge and usefulness of knowledge supplied by client network}

To develop customer relationships in a market is costly. These costs may concern financial investments, manpower investments, and investments in developing the market. Frequently, parts of these investments are either client specific or market specific and lack an alternative use (Anderson and Weitz 1992). High costs thus reflect a high degree of cooperative relationship development, where idiosyncratic investments have been made between the firm and its 
customer (Anderson and Narus 1990). ${ }^{4}$ Firms that perceive high costs have thus made unique adaptations (Hallén et al. 1991), and these adaptations are costly because they involve integration of production with the surrounding network (Blankenburg Holm et al. 1999). Thus, we postulate that cost aspects are likely to influence the manager's perception of the usefulness of knowledge supplied by client networks. More specifically, a higher perceived cost of a customer relationship will lead to a higher perceived usefulness of knowledge supplied by client network ties.

H3: The greater the perceived cost of cooperation in an ongoing business relationship, the greater the perceived usefulness of knowledge supplied by client networks.

In any buyer-seller exchange there is always a degree of uncertainty (Håkansson and Wootz 1975; Håkansson, Johansson, and Wootz 1976). Buyer-seller relationships contain uncertainties associated with the firm, its relationship to the suppliers and other clients, and the surrounding environment (Achrol and Stern 1988, Eriksson and Sharma 2003). Firms may use knowledge supplied by the client network in order to reduce uncertainty. The knowledge supplied by client network ties gives the firm a conduit to the uncertainties surrounding the firm, since the environment is connected to the relationship via the network (Blankenburg Holm et al. 1999). The knowledge supplied by client network ties may therefore reduce the uncertainty in the firm's relationships with other clients and suppliers. As stated earlier, information supplied by client and supplier is more akin to Granovetter's (1973) strong ties. They are more reliable, credible, and easy to use. But, client and supplier ties supply information that the firm is already familiar with. The firm may therefore reduce their uncertainty regarding other client and supplier ties more from the knowledge supplied by client network ties, which is more innovative, than from the more routine knowledge supplied by client ties. Thus knowledge from client network ties brings a superior diversity of knowledge. The firm that needs knowledge on other clients and suppliers may therefore 
perceive a greater usefulness of the information supplied by the client network in order to reduce this need for knowledge about ties to suppliers and other clients. Consequently,

H4: The greater the need for knowledge about the firm's other clients and suppliers, the greater the perceived usefulness of client networks will be.

\section{Knowledge of a variety of country markets and usefulness of knowledge supplied by client networks}

Earlier, we stated that current theory-in-use in firms determine its present and future business activities. This may concern the scope of learning, as well as its content. In addition, this may concern strategic, but also operative, marketing decisions (Eriksson et al. 1997). When firms start their internationalization, the theory-in-use in firms is based on their local and domestic market experience ${ }^{3}$. As firms operate in a variety of country markets, more knowledge, as well as different types of knowledge, are accumulated in the routines, structures, and programmed decision making processes of the firms. Variety in operations increases the number of different network actors that a firm exchanges knowledge with (Eriksson et al. 2000). Firms operating in a variety of country markets are exposed to different types of institutional, cultural, technical, and business actors. Operations in diverse country markets will expose the firm to different clients, competitors, a diverse set of institutional rules, norms, regulations, and market operations modes (Argyris 1996; Miller 1993; Miller and Chen 1994, 1996; Barkema et al. 1996; Weber, Shenkar and Raveh 1996).

Operations in varied country markets make the firm accumulate more knowledge and more differentiated types of knowledge (Mezias and Glynn 1993; Kiesler and Sproull 1982). 
Davidson (1980; 1983) and Erramilli (1991) found that firms that are exposed to limited variation accumulate limited knowledge on the institutions and clients that exist in a given market and the principles on which they operate. Firms with a variety of knowledge are better at spotting problems, errors, and opportunities. They understand the knowledge they need better and the value of the knowledge. Firms that operate in varied markets develop a broader knowledge base and more capabilities for the handling of business problems. These determine their ability to absorb and apply new knowledge to solve business problems. Research shows that such firms are likely to search for more information, rate more knowledge as useful, and weigh the 'soft' information in their decisions (Perkins and Rao 1990; Sujan, Sujan and Bettman 1988). That the knowledge of client networks is varied suggests that there is a need also for the knowledge of the firm to be varied. It can therefore be expected that firms with more varied stock of knowledge know how to use the client network better. Thus, we hypothesize that firms that operate in varied markets perceive knowledge supplied by client networks more useful.

H5: The greater the firm's variety of country markets, the greater the perceived usefulness of knowledge supplied by client networks will be.

\section{Data and Method}

The hypotheses are tested on a sample of 494 firms in small and medium sized manufacturing firms. Data was gathered by means of a questionnaire which was answered by a key informant, usually the CEO of the responding firms. The questionnaire was dispatched in 1998, to 1830 firms in Sweden, Denmark, and New Zealand. The companies were selected from the trade directories in the respective countries, and the selection criteria were that the firms should have at 
least $10 \%$ international sales and $50-200$ employees. The overall response rate is $27 \%$, with a national distribution of 27\% in Denmark (201 firms), 20\% in New Zealand (117 firms), and 35\% in Sweden (176 firms). Using Armstrong and Overton's (1977) method, there is no detectable non-response bias for key background factors, such as age and size in terms of number of employees. The responding firms had a median age of 31 years, with 18 years international business experience. The firms in the Swedish sample are a bit older, with a median age of 50 years. The median age of firms in the New Zealand sample is 23, and 29 in the Danish one. The median number of domestic employees is 63 employees, and 3 abroad. The responding firms do international business in a median of 11 countries, with median international sales of $30 \%$ in their biggest market. The internationalization of most of the Swedish and Danish firms have started in the Nordic countries and Germany, whereas 52\% of the New Zealand firms made their first international business in Australia.

The questionnaire design captures the usefulness of knowledge supplied by client networks. We earlier defined usefulness of knowledge as 'the perceived potential the information has for usage' (Menon and Varadarajan 1992, p. 66). The usefulness of knowledge is the ability of the knowledge to provide decision-makers with a rationale upon which to make their decisions, and thereby to promote action (Shrivastava 1987). The questionnaire was therefore designed so that it identified a real life business decision making situation, and then went on to ask for characteristics of this situation, and the usefulness of various aspects of knowledge for business development. The decision making situation was an ongoing business relationship, and the reason for this selection is based on the notion that business to a large extent is characterized by incremental work within ongoing business. The respondents were therefore presented with the following field scenario introduction: 
'We would like you to select an ongoing business relationship where your company (If you work in a firm that is divisionalized or in other ways divided into units, answer for your business unit) is expanding. Preferably, this ongoing business relationship should be well underway so that you would have already started doing business with the counterparts. If this is not suitable for you, then we would appreciate it if you could choose a recently finished business relationship. Examples of this ongoing business relationship could be:

- A contract with a new distributor or agent in a new country.

- A considerable expansion of business with an existing customer.

- Doing business with one or more new customers within an existing market.

- Entering new country markets with your existing customers.

- Doing business with new customers within a new market.'

The respondents were instructed to:

'Choose an ongoing business relationship that is important to your firm. Business relationships can be long term and hard to separate from ongoing business activities, but this investigation wants to capture a larger change in ongoing business with a customer or distributor'. The questionnaire stated that 'If you have selected a distributor, answer as if the word customer means distributor'.

As an example of what a respondent considered an ongoing international business was a paint production facility in China. The firm had located an employee there three years prior to 
making their first sales. In their eighth year of establishment they had built a factory to service the car plant, which was their primary customer.

The chosen business relationship had been going on for a median age of two years for the Swedish and New Zealand firms, and one year for the Danish firms. The median number of previous ongoing business relationships in the host country was two for each of the country samples. Most of the ongoing business relationships took place in the Nordic countries, Germany, Australia, or the USA.

The questionnaire was divided into three sections; the first relates to the need for knowledge, the second to the usefulness of knowledge, and the third concerns firm experience. The usefulness of knowledge supplied by client network ties can thus be studied against both a specific decisionmaking situation and the experience of the firm.

Ten test interviews were performed to validate the questionnaire. During these test interviews, respondents were asked to complete the questionnaire and say how they interpreted each question. Two researchers made each of the interviews, and cross-compared respondents interpretation of the questions after each interview. The object of the test interviews was to investigate the correspondence between the researchers' and the respondents' assessment of the questions. After revisions the survey was mailed to firms in the different countries, where local researchers were in charge of collecting the data, with the purpose to construct a common database. Data was computed by means of a structural equation modeling technique named LISREL. The validity of LISREL models is assessed in a two-step procedure. The first step is to test construct validity, and the second step is to test the validity of the entire model (Jöreskog and Sörbom 1993 pp. 120-128).

Since the validity of constructs may differ with the context of a structural model, it is recommended that the validity of constructs is tested not only in the structural model, but also in a measurement model without causal relations between constructs (Anderson and Gerbing 
1988; Jöreskog and Sörbom 1993). We consider all constructs to be reflective, following the recommendations of Bagozzi (2007).

\section{Construct Validity}

The constructs used as building blocks in the structural model need to be assessed for their validity before they can be used as building blocks in the model. They are analyzed in the context of the resulting structural model, and the loadings and indicators are almost the same as in the measurement model.

The perceived usefulness of client network ties is operationalized in three different kinds of ties: First, customers' customers are extensions forward along the value chain. Second, the customers' supplementary suppliers are vertical and potential cooperative partners to the firm. Third, competing suppliers are important for a firm's attempts to safeguard the network against opportunism. The t-values, factor loadings, and R2-values show that the construct validly captures the three indicators (see table 1)..

\section{Put Table 1 here}

Country market variation captures the firm's experience from many different country markets. This is measured as a single item question that relates to the number of country markets that the firm operates in (Erramilli 1991, Eriksson et al. 2000). The variable is logarithmically transformed. 
The involvement in the ongoing business relationship captures the depth of knowledge about the relationship. The involvement is consequently represented by both the duration in the ongoing business relationship, and the cognitive familiarity with it. The first indicator focuses the duration in the business relationship, which represents the temporal experience of the business relationship. Responses range from 0 to 40 years, and the variable was therefore logarithmically transformed and there was a control for outliers on very long business relationships. The second indicator focuses the perceived familiarity with the ongoing business relationship. The construct loads almost equally on the indicators, showing that they are equally well represented by the construct.

The standardization in the business relationship is assessed from the most important product, or service. This is measured as a single item question that relates to the degree of standardization of the firm's most important product or service offered to this client, on a 7point scale.

The need for knowledge about the ties to other clients and suppliers focuses on a firm's exchange with clients and suppliers. The t-values, factor loadings, and R2-values show that the construct 'need for knowledge in ties to other clients and suppliers' captures both the needs for knowledge about other clients and suppliers very well. The construct represents a variety of ties to other clients and suppliers that exist.

The perceived cost of an ongoing business relationship attempts to capture both the initial costs and the adaptations in ongoing business. The three indicators therefore focus on perceived cost of both gaining new clients and developing and cooperating with existing ones. The construct thereby captures the attraction, maintenance and development phases (Grönroos 2000). The construct is valid, as can be seen by t-values, factor loadings, and R2-values. 


\section{Results}

The results show how firms learn in ongoing business relationships, and how the firm's knowledge base affects this learning. The results are put together in a structural model presented in Figure 2. The model is valid since the model Chi-square is 53.95, with 41 degrees of freedom, and at a probability of 0.08 . Additional measures of model fit are also good, since the RMSEA is 0.02 , GFI is 0.98 , and the CFI is 0.99 . There are no correlated error terms or other modifications to the model, which is also good.

The results show that greater involvement in the client relationship leads to greater perceived usefulness of knowledge from client networks (coefficient is 0.18 , t-value is 2.44 ), which supports hypothesis 1.

\section{Put Figure 2 here}

Hypothesis 2 stated that the less standardized the product supplied by a firm, the more the perceived usefulness of knowledge supplied by the client network will be. This is not supported by the results. Instead, a greater degree of standardization leads to greater usefulness of knowledge supplied by client network (coefficient is 0.11 , t-value is 2.24 ). This result may be due to the fact that issues related to un-standardized products need to be resolved at the core of the relationship, which is why the knowledge supplied by the client network is not context specific enough and perceived as too novel. Support for this line of reasoning is given by studies pointing to the importance of idiosyncratic investments and 'sticky' information in relationships (Anderson and Weitz 1992, Tyre and von Hippel 1997). 
The findings in Figure 2 also show that a higher perceived cost of relationship development leads to greater perceived usefulness of client networks (coefficient is 0.20 , t-value is 3.51). This supports hypothesis 3 .

The need for knowledge about ties to other clients and suppliers gives greater perceived usefulness of knowledge from client networks (coefficient is 0.38 , t-value is 6.09), supporting hypothesis 4 .

Country market variation represents the firm's experience of country markets. The results are that more experienced firms find knowledge from client networks more useful (coefficient is 0.19 , t-value is 3.72), which supports hypothesis 5.

To test the robustness of the model, we first re-created the model using listwise deletion. This yielded a sample of 360 firms, and in general, the key statistics were similar to those presented above.

A second test of robustness was made by determining the sensitivity to industry, target country, domestic country, variation, duration in ongoing business relationship, age, and size. Partitioning the sample according to product or service showed no differences in-between the two samples. Partitioning the sample according to whether the target country was in the same or different cultural cluster revealed no major differences, and we have thus controlled for the models sensitivity to target country variation. There was no substantial difference between the three country samples. Partitioning the sample revealed sensitivity to variation. A group of firms active in less than 6 countries (81 firms) differed much from firms with more than 6 countries (279 firms). Due to missing values on the selection variable, listwise deletion was used in group analysis. The sample containing firms that had experience from more than 6 countries is similar to the model for the entire sample, whereas the sample for firms with experience from less than 6 countries show that the usefulness of client network depends primarily on the need for knowledge on other clients and suppliers. However, the sample for 
this group is only 81, so there is a need to check this difference against a larger database before conclusive results can be drawn. There was no substantial difference between long and short duration in ongoing business relationship, for cutoff points at 3 and 5 years. There was no difference at all between young and old firms at a cutoff of 10 years. There were differences between large and small firms, when the cutoff was set at 50 employees. However, in all of the above cases, the differences were in terms of the strength of the loadings, meaning that the model is valid in all cases, but the strength of the coefficients for causal effects varies.

A much debated issue concerns whether single-item constructs are identical to their indicators. On the grounds that the construct ought to differ somewhat from the indicator, Jöreskog and Sörbom (1993) have suggested an arbitrary reliability of 0.85 . To test the model's sensitivity to reliabilities of the two single item constructs, the reliabilities were varied between 0.70 , 0.80, and 0.90 . The analysis showed no major alteration of the model.

The robustness of the model may be due to that the perceived usefulness of knowledge about the client's network is a part of the knowledge development process in the internationalizing firms. Such processes have been found to exist in firms with very different properties, although the processes may differ in intensity and frequency (Autio, Sapienza and Almeida 2000).

\section{Discussion, Conclusions and Implications}

In this paper, we have investigated the perceived usefulness of knowledge from client networks. In our opinion, there exists an important gap in current research in international business. This concerns our knowledge on the usefulness of business information supplied by firms' client networks. Our purpose was to fill this gap in the current body of research on the network approach to International Business and the usefulness of market knowledge. Based on research 
on networks and usefulness of knowledge in international business, five hypotheses were generated and tested on a sample of 494 international firms.

Hypothesis 1-2 focused different characteristics of the client relationship, and their effect on the perceived usefulness supplied by client networks. In broad terms, hypotheses 1 and 2 support the fact that more knowledge development in a client business relationship leads to greater perceived usefulness of knowledge supplied by the client network. This is a strong support for the learning effect in a firm's relationships with clients. Hypothesis 1 proposed a positive relationship between the involvement in an ongoing business relationship and the perceived usefulness of knowledge from the client network. This is supported. A great involvement with clients in business relationships leads to a more embedded mode of knowledge accumulation, which involves coordination with client networks. The knowledge supplied by client networks is, consequently, perceived as useful.

Findings on $\mathrm{H} 2$ are that a more standardized main product supplied to clients leads to greater use of knowledge supplied by client networks. This does not support Hypothesis 2, which stipulated a negative relationship between degree of standardization of product supplied by firms and the perceived usefulness of knowledge supplied by client networks. The logic underlying hypothesis 2 is that supply of standardized products, implies a programmed and repetitive decision situation. Little, if any, new knowledge is needed. In such decision situations, firms generally know their market, clients, competitors and distribution channels. However, decision situations concerning the marketing of products on new and/foreign markets involve a high degree of uncertainty and risk. Decision-makers may perceive a need to develop new business strategies and tactics. The current theory-in-use in firms may need either major modification or a total re-modeling. The firms may need new knowledge. Programmed and routine decision processes are not adequate for such business decision situations. Client networks supply knowledge that is novel and different. However, for reasons that we can only speculate on, firms perceive their client 
networks as more useful the more standardized the product. We may speculate that the nature of adaptive learning is highly situation specific, implying learning about idiosyncratic investments. Such learning often involves a second order-learning, where the theory-in-use is re-structured, and such learning is difficult to accomplish in real life (Argyris and Schön 1978). This result calls for more research. Is there a limit to which kind of knowledge can be supplied by client networks? What kind of mechanisms in the firm affect the use of client networks in learning about idiosyncratic business problems?

We also examined the effect of local market experiences. Hypothesis 3 stipulated a relationship between cost of cooperation in the ongoing business relationship and the perceived usefulness of knowledge supplied by client networks. This is supported in the data. There is a positive correlation between cost of cooperation and the perceived usefulness of knowledge supplied by client networks. In our interpretation, as the cost of cooperation in a business relationship in markets increase, managers seek knowledge that can reduce these costs. Usually this knowledge can be found in the firm's previous experiences of and daily activities in business networks. The knowledge needed is frequently also novel, non-routine, uncertain, and consequently open to alternative interpretations, politics and controversy. In costly client relationships and projects, decision-makers, therefore, perceive knowledge supplied by client networks as more useful.

$\mathrm{H} 4$ stated that the greater the need for knowledge about ties to other clients and suppliers is, the greater the perceived usefulness of knowledge supplied by client networks. This was supported. The knowledge supplied by client networks seems to complement the knowledge supplied by a firm's ties to other clients and suppliers. This could be because the knowledge supplied by client networks is perceived to be useful for the reduction of uncertainty in ties to other clients and suppliers. Client network ties may span structural holes (Burt 1982) and can thereby supply knowledge that decreases the uncertainty in ties to other clients and suppliers. Similarly, the perceived usefulness of knowledge supplied by the client network may vary with what Menon 
and Varadarajan (1992) called action-oriented use, knowledge-enhancing use, and affective use of knowledge. To shed more light on these issues, more research is suggested. Furthermore, we suggest more research on whether the perceived usefulness of knowledge supplied by client networks is related to the stages in the international business decision making process. We need to improve our knowledge about whether the perceived usefulness of knowledge supplied by client networks varies with the stages in the decision process, namely, problem definition, generation of alternatives, evaluation of alternative courses of action, and choice of alternatives, for example.

Finally, we examined firm variety of country markets and its effect on the usefulness of knowledge supplied by client networks. Hypothesis 5 focused on the effect of generalized knowledge from many markets on the usefulness of knowledge supplied by client networks. H5 hypothesized a positive relationship between variation and the perceived usefulness of knowledge supplied by client networks. H5 is supported in the data. Our results show that the more variation in country markets there is in a firm's operations, the greater the perceived usefulness of the knowledge supplied by client network ties. Thus, variation or diversity in operations, per se, is sufficient to cause an increase in the perceived usefulness of client network ties. Firms with a greater variation in operation are engaged in a variety of differentiated networks and may have a larger number of network ties. This does improve the perceived usefulness of knowledge supplied by the client network.

To summarize the findings of this paper, we find support for that knowledge at the level of the ongoing business relationship, local markets, and varied country markets all have a positive effect on the perceived usefulness of client network ties. This result corroborates the strategic importance of knowledge of client networks in international business. This paper has taken a first step at identifying the importance of the client networks, and much future research is needed. 
This paper implies that perceived usefulness of client network ties increases performance. However, the performance associated with perceived usefulness of customer networks is difficult to measure, since the performance should relate to the relationship currently being analyzed. Accounting data is not available. The questionnaire instrument used here asks a set of questions on perceived benefits, satisfaction, cost, and benefit from the current business relationship. Based on analysis of correlations, client network ties improve a firm's ability to do business in new markets, decreases the cost of relationship development, and increases benefits from international business relationships.

Other limitations of this paper include the sample’s focus on firms in small countries with a high degree of international business, and the focus on SMEs. There is a need for further research to study larger firms, and firms that are from larger country markets, where the domestic sector better matches the international.

In this paper, we identify three types of client network ties that supply useful information. These are vertical, horizontal, and competitor ties. Future studies could investigate the relative importance of these three types of ties. Another issue for future research is to include more types of client networks, such as institutional actors.

These findings have implications for internationalization decision-makers in a number of ways. It seems as if experiences tend to increase the firm's use of new knowledge. This may be consistent with the grafting of core strategies, and the use of business models. This is done as firms gain experience both within an ongoing business relationship, within a market, and in their business globally. For firms the knowledge from client networks is a part of their business models and core strategies.

Based on the above discussion, we may speculate that the perceived usefulness of client ties and client network ties may be complementary. Decision-makers perceive knowledge supplied by 
client network ties to be useful in non-programmed, non-routine, and new marketing situations. In more programmed and routine marketing decision situations, on the other hand, knowledge supplied by client network ties is perceived to be less useful. However, knowledge supplied by ties to clients may be more useful in such conditions. On this issue, we suggest more research. More research is also needed to test if our findings are sensitive to cultural differences among nations. Similarly, the usefulness of networks may differ by industry, and this needs to be researched further. The biotech industry is known to have large networks of firms, whereas many manufacturing industries have smaller networks. While the research presented her presents findings that show the usefulness of the knowledge supplied by client networks, much further research is needed on foreign clients’ networks.

\section{Notes}

1: As pointed out by Menon and Varadarajan (1992), in extent research, terms such as ‘knowledge utilization', ‘information utilization', 'research utilization', 'research knowledge utilization', 'utilization', and 'use' are used interchangeably. In this paper we use the term knowledge use.

2: Researchers make a distinction between two different types of network embeddedness: relational and structural embeddedness. See Gulati (1998).

3: There are exceptions, however. An increasing number of firms operate abroad from their inception (Oviatt and McDougall 1994, 1995). 
4: In Transaction cost analysis, the association between perceived cost and relationship development is recognized in terms of 'credible commitments' that exchange partners make (Williamson 1985). Credible commitments are adjustments specific to a counterpart, which ties the exchange partners to the relationships since it is a sunk cost that has little or no value outside the relationship. This is similar to the arguments presented by social exchange theorists. 


\section{REFERENCES}

Achrol, Ravi S., and Stern, Louis W. (1988), “Environmental Determinants of Decision-

Making Uncertainty in Marketing Channels”, Journal of Marketing Research, XXV/feb, 3650.

Anderson, James. C. and David W. Gerbing (1988), “Structural Equation Modeling in Practice: A Review and Recommended Two-Step Approach,” Psychological Bulletin, 103/3, $411-23$.

Anderson, James. C., Håkan Håkansson, and Jan Johanson (1994), “Dyadic Business Relationships within a Business Network Context,” Journal of Marketing, 58/October, 1-15. Anderson, James C. \& James A. Narus. 1990. A model of distributor firm and manufacturer firm working partnerships. Journal of Marketing, 54/January, 42-58.

Anderson, Erin and B. Weitz (1992), “The Use of Pledges to Build and Sustain Commitment in Distribution Channels,” Journal of Marketing Research, 29/February, 18-34.

Autio, Erkko., Sapienza Harry J., Almeida James G. 2000. Effects of Age at Entry, Knowledge Intensity, and Imitability on International Growth. Academy of Management Journal, 41(5), 909-924.

Argyris, Chris (1996), “Actionable Knowledge: Design Causality in the Service of Consequential Theory,” The Journal of Applied Behavioral Science, 32/4, 390-406. Argyris, Chris and Donald. A. Schön (1978), Organizational Learning: A Theory of Action perspective. Addison-Wesley: Mass.

Armstrong, J. Scott and Terry S. Overton. (1977), Estimating non-response bias in mail surveys, “Journal of Marketing Research”, 14/3, 396-402. 
Bagozzi, Richard P. (2007), 'On the Meaning of Formative Measurement and How It Differs From Reflective Measurement: Comment on Howell, Breivik, and Wilcox’, Psychological Methods, 12/2, pp. 229-237.

Barkema, Harry G., John H. J. Bell and J. M. Pennings (1996), “Foreign Entry, Cultural Barriers, and Learning,” Strategic Management Journal, 17/2, 151-166.

Blankenburg Holm, Desirée, and Kent Eriksson (2000), “The Character of Bridgehead relationships”, International Business Review, No. 9, pp. 191-210.

Blankenburg Holm, Desirée, Kent Eriksson, and Jan Johanson (1999), “Creating Value Through Mutual Commitment to Business Network Relationships,” Strategic Management Journal, 20, 467-86.

Blomstermo, Anders, Kent Eriksson, Jan Johanson, and Deo Sharma (2000), “The Usefulness of Network Relationship Experience in the Internationalization of the Firm”, in Håkan Håkansson and Jan Johanson, Business Network Learning, Elsevier, UK.

Blomstermo, Anders, Kent Eriksson, Angelika Lindstrand and Deo Sharma (2004), “The perceived usefulness of network experiential knowledge in the internationalizing firm”, Journal of International Management, 10/3, 355-373.

Bridgewater, Susan (1999), “Networks and Internationalization: the case of multinational corporations entering the Ukraine”, International Business Review, 8, pp. 99-118.

Burt, Ronald S. (1982), Toward a Structural Theory of Action: Network Models of Social Structure, Perception and Action. New York: Academic Press.

Cavusgil, S. Tamer (1985), “Guidelines for Export Market Research,” Business Horizon, 28/5, 27-33. 
Chetty, S., Kent Eriksson \& Jessica Lindbergh (2006), 'The effect of specificity of experience on a firm's perceived importance of institutional knowledge in an ongoing business', Journal of International Business Studies, 37/5, pp. 699-712.

Cohen, Wesley M. and Daniel A. Levinthal (1990), “Absorptive Capacity: A New Perspective on Learning and Innovation,” Administrative Science Quarterly, 35/1, 128-52.

Corsini, Raymond J. (1987), Concise Encyclopedia of Psychology. New York: Wiley.

Daft Richard L. and Karl E. Weick (1994), “Toward a Model of Organizations as Interpretation Systems,” Academy of Management Review, 9/April, 284-295.

Davidson, William H (1980), “The Location of Foreign Direct Investment Activity: Country Characteristics and Experience Effects,” Journal of International Business Studies, 11/2, 9-22. Davidson, William H. (1983), “Market Similarity and Market Selection: Implications of International Marketing Strategy,” Journal of Business Research, 11/4, 439-56.

Davis Fred, Richard P. Bagozzi and Paul R. Warshaw (1989), “User Acceptance of Computer Technology: A Comparison of Two Theoretical Models”, Management Science, 35 /8, pp. 982-1003.

Delios, Andrew and Paul W. Beamish (2001), “Survival and Profitability: The Roles of Experience and Intangible assets in Foreign Subsidiary Performance”, Academy of Management Journal, 44/5, 1028-1038.

Deshpande, Rohit and Gerald Zaltman (1982), “Factors Affecting the Use of Market Research Information: A Path Analysis,” Journal of Marketing Research, 19/February, 14-31.

Duncan, R. and A. Weiss (1979), “Organizational Learning: Implications for Organizational Design,” In B. Staw and L.L. Cummings (eds.), Research in Organizational Behavior, 1, Greenwich, CT: JAI, 75-132. 
Dwyer, Robert F., Paul H. Schurr, and Sejo Oh (1987), “Developing Buyer-Seller

Relationships,” Journal of Marketing, 51/2, 11-27.

Eriksson, Kent, Jan Johanson, Anders Majkgård, and D. Deo Sharma (1997) “Experiential Knowledge and Cost in the Internationalization Process,” Journal of International Business Studies,28/2, 337-60.

Eriksson, Kent, Jan Johanson, Anders Majkgård, and D. Deo Sharma (2000), “Effect of Variation on Knowledge Accumulation in the Internationalization Process,” International Studies of Management \& Organization, 30/1, 26-44.

Eriksson, Kent and D. Deo Sharma (2003), "Modeling Uncertainty in Buyer-Seller Relationships", Journal of Business Research, Journal of Business Research, 56, 961-970.

Erramilli, M. Krishna (1991), “The Experience Factor in Foreign Market Entry Behavior of Service Firms,” Journal of International Business Studies, 22/3, 479-501.

Fiol, C. Marlene and Marjorie A. Lyles (1985), “Organizational Learning”, Academy of Management Review, 1/4, 803-13.

Ford, David (1980), “The Development of Buyer-Seller Relationships in Industrial Markets”, European Journal of Marketing, 14/5-6), 339-33.

Gilmore, Audrey, David Carson, and Steve Rocks (2006), “Networking in SMEs: Evaluating its Contribution to Marketing Activity”, International Business Review, 15/3, 278-293.

Goodman, Paul S., Mark Fichman, F. Javier Lerch, and Pamela Snyder (1995), “CustomerFirm Relationships, Involvement, and Customer Satisfaction”, Academy of Management Journal, 38/5, 1310-1324.

Granovetter, Mark (1973), “The Strength of Weak Ties,” American Journal of Sociology, 78/6, 1360-80. 
Grönroos, Christian (2000), Service Management and Marketing, Wiley: Chichester.

Gulati, Ranjay (1998), “Alliances and Networks”, Strategic Management Journal, 19/4, 293317.

Gundlach, Gregory T., Ravi S. Achrol, and John T. Mentzer (1995), “The Structure of Commitment in Exchange,” Journal of Marketing, 59/1, 78-92.

Hall, Carol (1984) “The Learning Curve, Demand Growth, and Market Concentration,” International Journal of Industrial Organization, 2/2, 147-57.

Hallén, Lars, Jan Johanson, and Nazeem Seyed-Mohamed (1991), “Interfirm Adaptation in Business Relationships”, Journal of Marketing, 55/April, 23-37.

Heide, Jan B and George John (1992), “Do Norms Matter in Marketing Relationships?” Journal of Marketing, 56/2, 32-44.

Hitt, Michael A., Robert E. Hoskisson and Hicheon Kim (1997), “International Diversification: Effects on Innovation and Firm Performance in Product Diversified Firms”, Academy of Management Journal, 40/4, 767-798.

Huber, George P. (1991), “Organizational Learning: The Contributing Processes and the Literatures,” Organization Science, 2/February, 88-115.

Håkansson, Håkan and Björn Wootz. (1975), “Supplier Selection in an International Environment - an Experimental Study,” Journal of Marketing Research, 12/February, 10-16. Håkansson, Håkan, Jan Johanson, and Björn Wootz (1976), Influence Tactics in Buyer-Seller Processes, Industrial Marketing Management, December, 319-32.

Jackson, Barbara (1985), Winning and Keeping Industrial Customers: The Dynamics of Customer Relationships. Lexington, MA: Lexington Books, Heath. 
Johanson, Jan and Lars-Gunnar Mattsson (1987), “Interorganizational Relations in Industrial Systems: A Network Approach Compared with the Transaction-Cost Approach,” International Studies of Management \& Organization, 17/1, 34-48.

Johanson, Jan and Jan-Erik Vahlne (1977), 'The Internationalization Process of the Firm - A Model of Knowledge Development and Increasing Foreign Market Commitments', Journal of International Business Studies, 8/1, 23-32.

Jöreskog, Karl-Gustav and Dag Sörbom (1993), LISREL 8: Structural Equation Modeling with the SIMPLIS Command Language. Chicago: Scientific Software International.

Kiesler, Sara and Lee Sproull (1982), "Managerial Response to Changing Environments: Perspectives on Problem Sensing from Social Cognition,” Administrative Science Quarterly, 27/4, 548-70.

Levinthal, Daniel A. and Mark Fichman (1988), Dynamics of Interorganizational Attachments: Auditor-Client Relationships, Administrative Science Quarterly, 33, 345-369.

Levitt, Barbara and James G. March (1988), “Organizational Learning,” W. Richard Scott and Judith Blake (eds.), In Annual Review of Sociology, Annual Reviews, Inc.: Palo Alto, CA, 3140.

Lindstrand, Angelika. (2003), 'How to Use Network Experience in Ongoing International Business', in A. Blomstermo and D. D. Sharma (eds.) Learning in the Internationalization Process of Firms. Edward Elgar, UK.

Lord, Frederick C. and Melvin R. Novick. 1968. Statistical Theories of Mental Test Scores. Reading, MA: Addison-Wesley.

Lou, Yadong and Mike W. Peng (1999), “Learning to Compete in a Transition Economy: Experience, Environment and Performance” Journal of International Business Studies, 30/2, 269-295. 
March, James G. (1991), “Exploration and Exploitation in Organizational Learning,” Organization Science, 2/1, 71-87.

March, James G. and J. P. Olsen (1976), Amibiguity and Choice in Organizations. Bergen, Norway: Universitetsforlaget.

March, James G. and Simon, H. A. (1958), Organizations. New York: Wiley.

Marsden, Peter V. and Karen E. Campbell (1984), "Measuring the Strength, “Social Forces, 63, 482-501.

Menon, Anil and P. Rajan Varadarajan (1992), “A Model of Marketing Knowledge Use within Firms,” Journal of Marketing, 56/October, 53-71.

Mezias, Stephen. J. and Mary Ann Glynn (1993), 'The Three Faces of Corporate renewal: Institution, Revolution, and Evolution', Strategic Management Journal, 14/February, 77-101.

Miller, Danny (1993), “The Architecture of Simplicity,” Academy of Management Review, 18/1, 116-38.

Miller, Danny and Ming-Jer Chen (1994), “Sources and Consequences of Competitive Inertia: A Study of the U.S. Airline Industry,” Administrative Science Quarterly, 15/2, 1-22.

Miller, Danny and Ming-Jer Chen (1996), “The Simplicity of Competitive Repertoires: An Empirical Analysis,” Strategic Management Journal, 17/6, 419-39.

Morgan, Robert A. and Shelby D. Hunt (1994), “The Commitment-Trust Theory of Relationship Marketing”, Journal of Marketing 58/July, 20-38.

Nelson, Richard and Sidney Winter (1982), An Evolutionary Theory of Economic Change. Cambridge, MA: Belknapp Press.

Oviatt, Benjamin M. and Patricia P. McDougall (1994), “Toward a Theory of International New Ventures,” Journal of International Business Studies, 25/1: 45-64. 
Oviatt, Benjamin M. and Patricia P. McDougall (1995), “Global Start-Ups: Entrepreneurs on a Worldwide Stage,” Academy of Management Executive, 9/2, 30-44.

Perkins, Steven W. and Ram C. Rao (1990), “The Role of Experience in Information Use and Decision Making by Marketing Managers,” Journal of Marketing Research, 23/February, 1-10.

Ranson, Stewart, Bob Hinings and Royston Greenwood (1980), “The Structuring of Organizational Structures,” Administrative Science Quarterly,” 25/1, 1-17.

Shahana, S. and A. Tuzhilin (1998), “Making Sense of Marketing Data: Some MIS Perspectives on the Analysis of Large Data Sets,” Journal of Market-Focused Management, 3/1, 91-111.

Shrivastava, Paul (1987), "Rigor and Practical Usefulness of Research in Strategic Management,” Strategic Management Journal, 8/1, 77-92.

Shrivastava, Paul and Susan Schneider (1984), “Organizational Frames of References,” Human Relations, 37/10, 795-809.

Simon, Herbert A. (1961), Administrative Behavior. New York: The Macmillan Company. Sinkula James M. (1994), “Market Information Processing and Organizational Learning,” Journal of Marketing, 58/1, 35-45.

Slater, Stanley F. and John C. Narver. (1995), “Market Orientation and the Learning Organization,” Journal of Marketing, 59/3, 63-74.

Sujan, Harish, Mita Sujan, and James R. Bettman (1988), “Knowledge Structure Differences Between More Effective and Less Effective Salespeople,” Journal of Marketing Research, 25/February, 81-86.

Tyre, Marcie J. and Eric Von Hippel (1997), “The Situated Nature of Adapted Learning in Organizations”, Organization Science, 8/1, 71-83. 
Venkatesh Viswanath and Fred D. Davis (2000), “A Theoretical Extension of the Technology Acceptance Model: Four Longitudinal Field Studies”, Management Science, 46/2, 186-205. Walter, Achim, Thilo A. Müller, Gabriele Helfert and Thomas Ritter (2003) ,'Functions of Industrial Supplier Relationships and Their Impact on Relationship Quality’ Industrial Marketing Management, 32/2, pp. 159-169.

Weber, Yaakov, Oded Shenkar, and Adi Raveh (1996), “National and Corporate Cultural Fit in Mergers/Acquisitions: An Exploratory Study,” Management Science, 42/8, 1215-27.

Weick, Karl (1969), The Social Psychology of Organizing, Reading, MA.: Addison-Wesley. Welch, Catherine and Ian Wilkinson (2005) “Network Perspectives on Interfirm Conflict: Reassessing a Critical Case in International Business”, Journal of Business Research, 58/2, pp. 205-213.

Welch, Catherine and Ian Wilkinson (2004) “The Political Embeddedness of International Business Networks”, International Marketing Review, 21/2 pp. 216-231.

Wilkinson, Ian F. and Louise C. Young (2005), “Toward a Normative Theory of Normative Marketing Theory”, Marketing Theory, 5/4, pp. 363-396.

Williamson, Oliver E. (1985), The Economic Institutions of Capitalism. New York: The Free Press.

Zinkhan, George M., Erich A. Joachimsthaler, and Thomas Kinnear (1987), “Individual Differences and Marketing Decision Support System Usage and Satisfaction,” Journal of Marketing Research, 24/May, 208-14. 
Appendix. Correlation Matrix and Descriptive Statistics.

Indicator $\mid$ Means Standard

Abbreviation $\quad \begin{array}{ll}\text { Means } & \begin{array}{l}\text { Standard } \\ \text { Deviation }\end{array}\end{array}$

2.014

FAMILIAR

CUST

4.230
3.370

3.370
4.743

2.014

SUPPL

2.296
2.012

2.012

1.000

$2.091 \quad-0.003$

1.900

0.055

1.945

CSS

NEWC

PROD

COOP

1.147

0.092

1.209

0.026

1.216

0.059

$1.132-0.053$

0.053

\subsection{0}

0.025

$-0.016$

$-0.064$

$-0.087$

$-0.077$

0.011

0.050

$-0.046$

$-0.095$

0.283

\subsection{0}

0.585

$0.183 \quad 0.161$

$0.222 \quad 0.293$

$0.211 \quad 0.227$

$-0.120$

$-0.095$

$-0.171$

-0.151
-0.063

$-0.141$

$0.159 \quad 0.150$

$-0.030 \quad-0.036$

\subsection{0}

$0.603 \quad 1.000$

$0.407 \quad 0.545$

$-0.111-0.150$

$-0.125-0.155$

$\begin{array}{ll}-0.121 & -0.190\end{array}$

$\begin{array}{ll}-0.074 & -0.047\end{array}$

$-0.059 \quad-0.011$

1.000

$-0.080$

$-0.095$

$-0.065$

-0.065
-0.054

$-0.035$

1.000
0.254

0.286

0.093

0.603

-0.131
0.009

1.000

$-0.058$

1.000

\begin{tabular}{ll}
\hline Indicator Abbreviation & Question Put in Questionnaire \\
\hline STAND & What is the degree of standardization of the most important product in this business relationship? \\
FAMILIAR & This business relationship is different from previous ones because the customer is: <new - very familiar to our firm> \\
CUST & Need for knowledge about our customer's products is an obstacle when developing this business relationship \\
SUPPL & Need for knowledge about our supplier's product is an obstacle when developing this business relationship \\
CC & In developing this business relationship we can use experiences from previous relationships with customer's customers. \\
CSS & In developing this business relationship we can use experiences from previous relationships with customer's supplementary \\
& suppliers. \\
COMP & In developing this business relationship we can use experiences from previous relationships with competing suppliers. \\
NEWC & What is your assessment of the cost in gaining new customers? \\
PROD & What is your assessment of the cost in development of new products for your customer? \\
COOP & What is your assessment of the cost in development of cooperation in general with your customer? \\
VARIAT & In approximately how many countries do you operate? \\
DURASG & For how long has this business relationship been going on? < Logarithmic transformation and ten categories of equal length> \\
\hline
\end{tabular}


TABLE 1

The Constructs and their Indicators

\begin{tabular}{|c|c|c|c|c|}
\hline Indicator & $\begin{array}{l}\text { Abbreviation } \\
\text { in Figure } 1\end{array}$ & $\begin{array}{l}\text { Factor } \\
\text { Loading }\end{array}$ & t-value & $\begin{array}{l}\mathrm{R} 2 \\
\text { value }\end{array}$ \\
\hline \multicolumn{5}{|l|}{ Usefulness of client network } \\
\hline $\begin{array}{l}\text { In developing this business relationship we can use } \\
\text { experiences from previous relationships with customer's } \\
\text { customers. < Fully disagree - Fully agree }>\end{array}$ & $\mathrm{CC}$ & 0.67 & 12.08 & 0.45 \\
\hline $\begin{array}{l}\text { In developing this business relationship we can use } \\
\text { experiences from previous relationships with customer's } \\
\text { supplementary suppliers. }\end{array}$ & CSS & 0.89 & 12.52 & 0.80 \\
\hline $\begin{array}{l}\text { In developing this business relationship we can use } \\
\text { experiences from previous relationships with competing } \\
\text { suppliers. }\end{array}$ & COMP & 0.61 & 11.76 & 0.38 \\
\hline \multicolumn{5}{|l|}{ Country market variation } \\
\hline $\begin{array}{l}\text { In approximately how many countries do you operate? } \\
\text { (Logarithmic transformation) }\end{array}$ & VARIAT & 1 & & 1 \\
\hline \multicolumn{5}{|l|}{ Involvement in relationship } \\
\hline $\begin{array}{l}\text { For how long has this business relationship been going on? } \\
\text { (Logarithmic transformation) }\end{array}$ & DURASG & 0.50 & 5.32 & 0.25 \\
\hline $\begin{array}{l}\text { This business relationship is different from previous ones } \\
\text { because the customer is: <new - very familiar to our firm> }\end{array}$ & FAMILIAR & 0.58 & 5.49 & 0.34 \\
\hline \multicolumn{5}{|l|}{ Standardization } \\
\hline $\begin{array}{l}\text { What is the degree of standardization of the most } \\
\text { important product in this business relationship? } \\
\text { <very customized - very standardized }>\end{array}$ & STAND & 1 & & 1 \\
\hline \multicolumn{5}{|l|}{ Need for knowledge on other clients and suppliers } \\
\hline $\begin{array}{l}\text { Need for knowledge about our customer's products is an } \\
\text { obstacle when developing this business relationship }<\text { Fully } \\
\text { disagree - Fully agree }>\end{array}$ & CUST & 0.74 & 12.51 & 0.55 \\
\hline $\begin{array}{l}\text { Need for knowledge about our supplier's product is an } \\
\text { obstacle when developing this business relationship }\end{array}$ & SUPPL & 0.79 & 13.01 & 0.62 \\
\hline \multicolumn{5}{|l|}{ Perceived cost of relationship } \\
\hline $\begin{array}{l}\text { What is your assessment of the cost in gaining new } \\
\text { customers? < No cost - Very high cost }>\end{array}$ & NEWC & 0.36 & 7.20 & 0.13 \\
\hline $\begin{array}{l}\text { What is your assessment of the cost in development of } \\
\text { new products for your customer? }\end{array}$ & PROD & 0.73 & 13.37 & 0.54 \\
\hline $\begin{array}{l}\text { What is your assessment of the cost in development of } \\
\text { cooperation in general with your customer? }\end{array}$ & COOP & 0.82 & 14.33 & 0.67 \\
\hline
\end{tabular}


FIGURE 1.

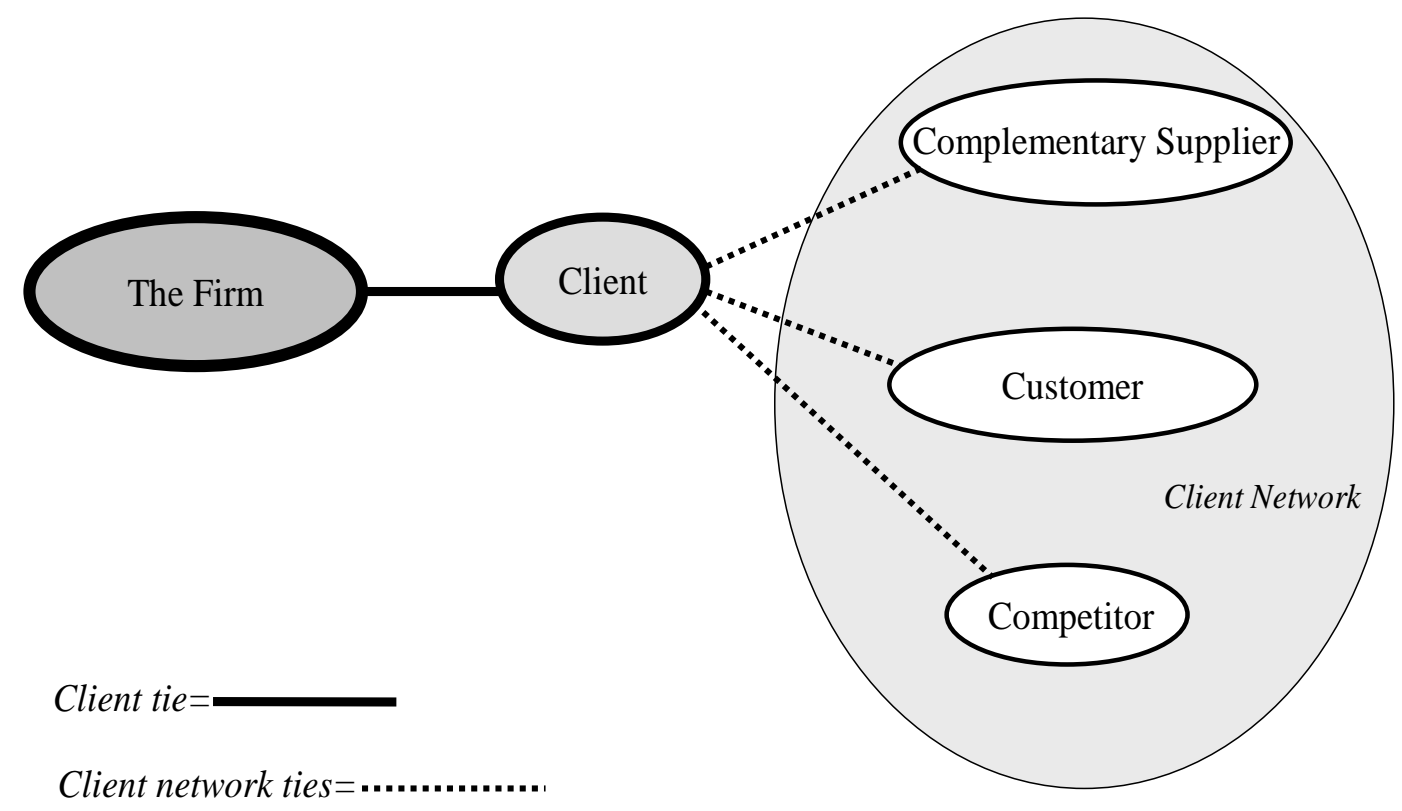


FIGURE 2

The Resulting Structural Model

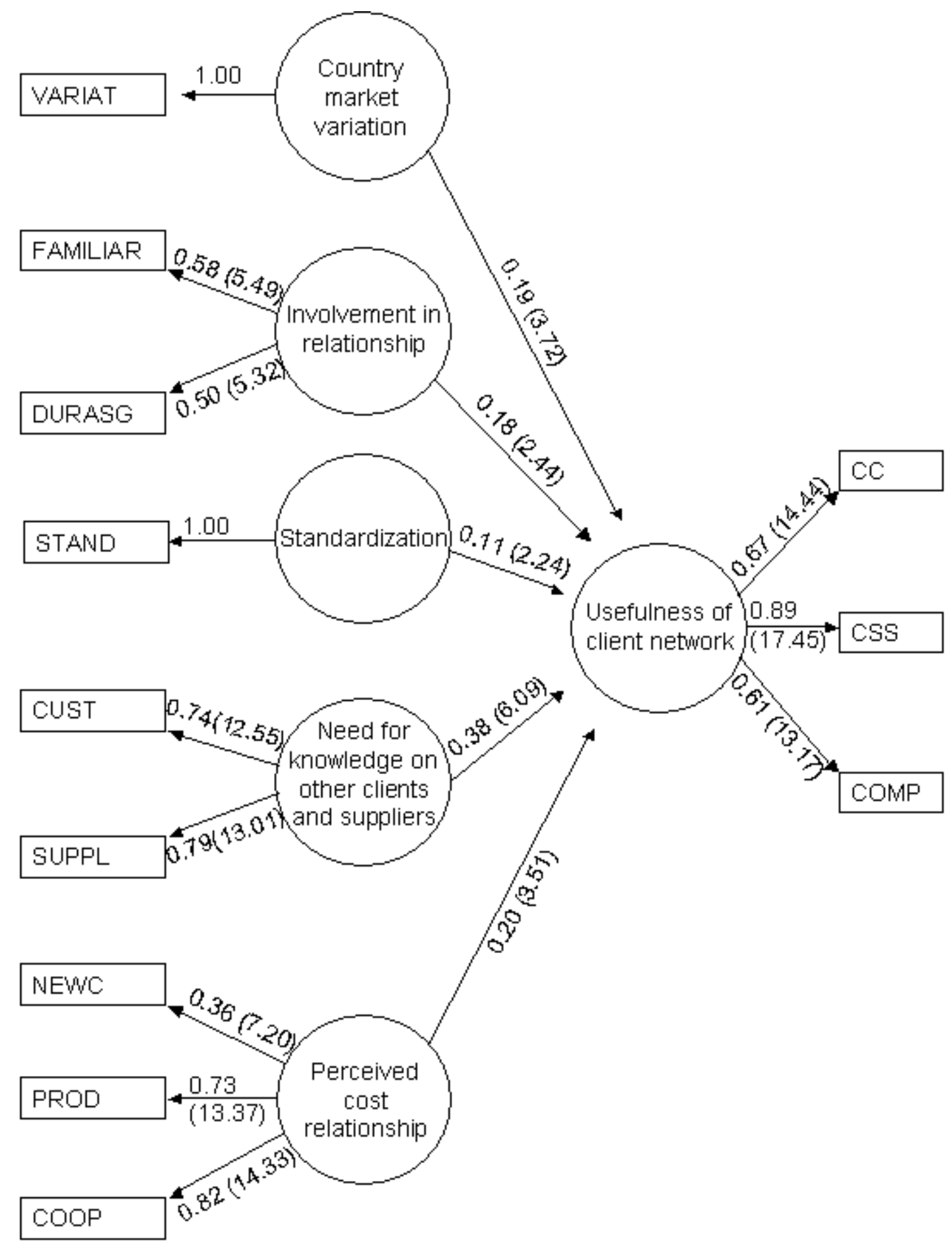

Note: Model Chi-square is 53.95, with 41 degrees of freedom, and at a probability of 0.08 . RMSEA is 0.02 , GFI is 0.98 , and the CFI is 0.99 . 
